\title{
Design of Bag Product's Marketing Strategy by Implementing QFD Method and SWOT Analysis
}

\author{
${ }^{1}$ NUGRAHA, ${ }^{2}$ DINA DIEN NOVITA, ${ }^{3}$ DJAMALUDIN, ${ }^{4}$ ARBA'IYAH SATRIANI \\ ${ }^{1234}$ Universitas Islam bandung, Jl. Taman Sari No. 1, Jawa Barat, Indonesia, \\ Correspondence Authour: nugraha692016@gmail.com;
}

\begin{abstract}
Production of children's backpacks has experienced a decline in sales over the past three years. This is experienced by CV Semesta Agung (SA), a textile company that produces t-shirts, jeans, and children's backpacks. The decline of children's backpacks sales occurred because of the large number of competitors and it needs a solution to overcome it. This research aims to design the marketing strategy by implementing QFD method and SWOT analysis. The method used is Quality Function Deployment (QFD) stage one, which is a matrix creation of House of Quality (HOQ) and SWOT. Based on the findings of the research, there are several product attributes that should be considered in a production of children's backpack, such as attractive design/motif, the quality of materials and stitches, affordable price, and product durability. In addition, based on this research, it can be concluded that several marketing strategies can be implemented by companies, which is gained from SWOT method. The first one is WO strategy that can be done by expanding a marketing area in Bandung city, improving packaging design, providing product warranty, giving discount, and manufacturing waterproof children's backpack. The second one is ST strategy by improving quality of product and worker skills, as well as reducing production cost. The third one is WT strategy by designing more attractive bag products and creating a new product.
\end{abstract}

Keywords: marketing strategy, QFD, SWOT.

\section{Introduction}

The industry has experienced a rapid increase that encouraged businessmen to be able to compete in it. Garment industry is one of the vital industries which have a big contribution economically, both in absorbing labour and generating Bruto Domestic Product of Indonesia. Discussing the garment industry cannot be separated from discussing textile industry and product. It is because garment industry is part of the structure of textile industry and textile product in general. The textile industry structure is formed by several types of industries which establish a series from upstream to downstream. The upstream industry includes fiber, spinning and yarn industry, knitting, printing and finishing; while the downstream industry includes garment industry. The entire product of the textile industry subsector is often called the
Textile industry and Textile Products (TITP). The textile industry and garment industry is a type of industry that has a very high competition since fashion has a crucial role in the society in this era (Munadi, 2015). The textile and garment of small and medium industries in Bandung city, in 2017, reached $54 \%$ and dominated other industries (BPS, 2017).

CV. SA is a textile industry company that produces t-shirts, jeans and children's backpacks located in Bandung. From the interview with the managers and employees, as well as based on secondary data, in the last three years, the company has experienced a decline in sales, especially in children's backpack products. This is triggered by many new competitors that are producing similar products. Sales of children's backpacks have decreased continuously over the past 3 years with a total of 2,293 products. Based

Received: December 08, 2020, Revision: March 06, 2021, Accepted: June 03, 2021

Print ISSN: 0215-8175; Online ISSN: 2303-2499. DOI: https://doi.org/10.29313/mimbar.v37i1.7011

Accredited Sinta 2 based on the decree No.10/E/KPT/2019 until 2024. Indexed by DOAJ, Sinta, Garuda, Crossreff, Dimensions 


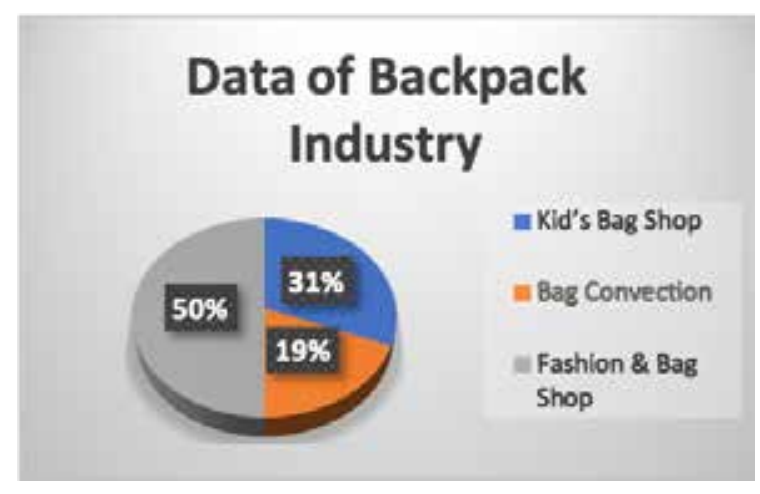

Figure 1. Competitor's Data

on this data, the average decline in sales of children's backpacks was 458 products per six months, and in the last year, the sales of children's backpacks reached 2,972. It means that the sales figure was below the sales of t-shirts that reached 3,454 t-shirts.

The decline in sales was due to several competing companies that also sell similar products. In addition, the company does not have a marketing strategy to overcome the decline of product sales which can be seen in figure 1 below.

The number of competing companies that sell similar products of children's backpacks is one of the factors that caused the decline in sales of the products. Based on the competitor's data that sell children's backpack products, fashion \& bag stores are dominating the market by $50 \%$, children's bag stores by $31 \%$, and bag convection by $19 \%$. The biggest decline in sales experienced by companies was found in children's backpack products, thus this study will focus on children's backpack products.

Based on the background of the problems, the aims of the research is to determine the product attributes that consumers want, the priority of product attributes, and the right marketing strategy for the company.

To find out the product attributes that consumers want, the priority of product attributes, and the right marketing strategies for the company, quality is one of the attributes that cannot be separated and must be considered in fulfilling the needs and expectations of consumers. Each product must have certain advantages to be able to compete in the market (Rucitra, 2020). By paying attention to the desires of consumers, a product development strategy can be developed. The desire of consumers will be filtered using the method of Quality Function Deployment (QFD) stage, 1 namely a matrix of House of Quality (HOQ), where QFD is a method that is used in the planning and product development process that specifically identifies consumer desires and needs. Through the QFD method, a company can find out the product attributes that consumers expect to satisfy. Quality Function Deployment (QFD) is a method of planning and developing a product/service in a structured manner that allows the development team to clearly define the needs and expectations as well as evaluate the ability of a product or service systematically to meet the needs and expectations (Rangkuti, 2013). Quality Function Deployment is a planning tool that is used to meet consumer expectations for the product. QFD is a method that has a positive impact on companies and is a tool and technique that is used freely to study the specific data collected from consumers (Gaszpersz, 2003). Producing products that meet consumer expectations need quality improvements that can be done through control of production process. The application of control process in an industry aims to determine the suitability of the process carried out by the company with predetermined standards. (E. P. Nurlaili, 2012).

The main planning tool in the Quality Function Deployment matrix is the House of Quality (HOQ). HOQ translates the voice of the consumer into the technical requirements of how the organization can meet those requirements. This is in accordance with the statement of Besterfield (2012). QFD's main tool is the matrix that is achieved through the use of interdepartmental or functional teams by prioritizing customer needs. It is called the voice of customers. The QFD process starts from the voice of the customer and then continues to four main activities, namely Product Planning, which is translating customer needs into technical requirements; Product Design, which translating technical requirements into component characteristics; Process Planning Identify to process steps and parameters and translate them into process characteristics; and Process Planning Control. Product development is the stage of analyzing market perceptions and opportunities, production, sales and delivery of products that are considered to have more value than previous products (Ulrich \& Eppinger, 2001). Meanwhile, product development 
needs an identification model that can be prepared using the concept of Quality Function Deployment (QFD) (Prabowo \& Zoelangga, 2019). The use of QFD will result in effectiveness and efficiency by creating an information exchange platform and providing a framework for stakeholders to optimize decision making (Dehe, B., \& Bamford, D. 2017). Andronikidis et al. (2009) and Murali, Pugazhendhi, and Muralidharan (2016) discuss the benefits of implementing QFD. They explain that QFD supports the reduction of new product development costs, reduces rework and design changes, and reduces the risk of failure (Koo, 2007). If it is viewed from internal and external aspects, the use of QFD method can be integrated with other methods in order to formulate strategic business unit policies. One of the best integration methods for QFD is the use of SWOT analysis. SWOT analysis is the identification of various internal and external factors of the company to formulate strategies by maximizing strengths and opportunities and minimizing weaknesses and company threats. The analysis of internal factors regarding the strengths and weaknesses of the company is obtained from the $\mathrm{HOQ}$ results, while the analysis of the external factors of opportunities and threats is obtained through brainstorming with the company. The method commonly used in conducting business environment analysis is SWOT analysis. SWOT analysis can identify external factors in the form of opportunities and threats to business continuity, and internal factors in the form of strengths and weaknesses that exist in the company.

Based on SWOT analysis, the main indicators can be found to formulate a strategy formulation. The formulation of a company strategy is basically done to get a formulation in which there is a balance between the strengths and the weaknesses of the company so that it is able to optimize opportunities and anticipate threats arise from business competitors (Subhan., 2017).

SWOT analysis is a systematic procedure to identify certain critical success factors applied by the company, such as the strengths and weaknesses as internal factors, and opportunities and threats as external factors (Blocher, Stout, \& Cokins, 2011). According to Wanti, Taufiqurrahman \& Rahayu (2014), SWOT analysis is a very important strategic planning tool to support a planning that compare the company's internal strengths and weaknesses with external opportunities and threats. In determining the target market, companies need to pay attention to the scale/number of segments determined and the existing competitive position in the targeted segment, so that there will be intense competition and business units need to focus on customers (Wijaya \& Sirine, 2016).

According to David (2009), the Strength-Weakness-Opportunity-Threat (SWOT) matrix is an important matching tool in helping managers to develop four types of strategies, namely SO strategy, WO strategy, ST strategy, and WT strategy. In addition, the Internal Strategic Factors Analysis Summary (IFAS) matrix is compiled to summarize and evaluate the strengths and weaknesses. Meanwhile, the External Strategic Factors Analysis Summary (EFAS) matrix is used to summarize and evaluate economic, social and cultural, demographic, political or governmental, legal, natural, technological, and competitive information (David, 2016). The two IFAS and EFAS matrices will produce an Internal External matrix to find out the position of the corporate-level business strategy in more detail (Javandira \& Gama, 2018).

\section{Research Methodology}

This research uses descriptive quantitative research which is conducted to raise various facts, situations and current phenomena and are presented with data. The research design used is a survey design in the form of questionnaires aimed to collecting samples from a predetermined .population

The research methodology is designed to determine the flow of the research process to be carried out and describe the stages of the research to solve the problem. The following is a series of procedures and steps in conducting research that aims to obtain a systematically structured stage. (1) Research Preparation stage. This stage includes the identification of the problem that is making direct observations to find a general description of the problems. The formulation of the problem consists of questions that become a reference for making research objectives, setting goals of the research as well as literature studies which are related to references about the formulation of business strategies such as EFE Matrix, IFE Matrix, TOWS/SWOT Matrix, Quality Function Deployment (QFD) and other 
Table 1.

Dimension of Product Quality

\begin{tabular}{ccc}
\hline No & Statement & Dimension \\
\hline 1 & Affordable bag price & Brand Name \\
2 & Attractive bag color & Fit and \\
& & Finish \\
3 & Interesting bag picture & Fit and \\
4 & Attractive Packaging Design & Finish \\
5 & Hanging accessories & \\
6 & Waterproof & Feature \\
7 & Multiple pockets & \\
8 & Bag capacity & Performance \\
9 & Light bag & \\
10 & Material quality & \\
11 & Zipper quality & Reliability \\
12 & The quality of sling & \\
13 & Stitch quality & \\
14 & Durable & Durability \\
15 & Warranty & Serviceability \\
16 & Small bag bonus & \\
\hline & &
\end{tabular}

Source: Data is processed from research, 2020

things that can make the research perfect. (2) The Data Collection stage. At this stage, the design of the questionnaire was carried out. This stage began with the making of an open questionnaire, a closed questionnaire and conducting a pretest, as well as distributing the actual questionnaire and conducting interviews with related parties. The distribution of open questionnaires aims to obtain the desires and needs of consumers for the products offered. The number of questionnaires distributed was 30. After the open questionnaires were processed, the next process was classifying the quality dimensions for the closed questionnaires.

The distribution of closed questionnaires is divided into two. The first is the distribution of the closed pretest questionnaire and the second is distribution of the actual closed questionnaire. The distribution of closed questionnaires used a research measurement tool Likert scale to measure attitudes, opinions, and perceptions of a person or group of people about social phenomena.

Closed questionnaires were distributed to respondents to obtain information about customer desire and an assessment of bag products. Prior to the distribution of actual questionnaires, the number of samples was determined first to decide the number of questionnaires that had to be distributed. The determination of the number of samples in this study was carried out based on the Slovin formula with a population of 191.634 respondents, with an error rate of $10 \%$ as follows:

$$
n=\frac{N}{1+N e^{2}}
$$

$$
\begin{aligned}
& n=\frac{191634}{1+191634 x(0.1)^{2}} \\
& n=99.94 \approx 100
\end{aligned}
$$

Explanation:

$\mathrm{n}=$ sample size

$\mathrm{N}=$ population size

$\mathrm{e}=$ percentage of concession

(3) Data Testing stage. After the closed questionnaire is distributed, data testing is carried out which consist of validity and reliability test. The validity test is conducted to determine whether the questionnaire to be distributed has the accuracy to be able to proceed to the next stage. The validity test was carried out using SPSS software. The complete validity test results are shown

\begin{tabular}{|c|c|c|c|c|}
\hline No & Statement & $\begin{array}{c}\text { Table } \\
\mathbf{r}\end{array}$ & $\begin{array}{c}\text { Count } \\
\mathbf{r}\end{array}$ & Result \\
\hline 1 & $\begin{array}{l}\text { Affordable bag } \\
\text { price }\end{array}$ & 0.306 & 0.494 & Valid \\
\hline 2 & $\begin{array}{l}\text { Attractive bag } \\
\text { color }\end{array}$ & 0.306 & 0.321 & Valid \\
\hline 3 & $\begin{array}{l}\text { Interesting bag } \\
\text { picture }\end{array}$ & 0.306 & 0.353 & Valid \\
\hline 4 & $\begin{array}{c}\text { Attractive } \\
\text { Packaging } \\
\text { Design }\end{array}$ & 0.306 & 0.394 & Valid \\
\hline 5 & $\begin{array}{l}\text { Hanging } \\
\text { accesories }\end{array}$ & 0.306 & 0.359 & Valid \\
\hline 6 & Waterproof & 0.306 & 0.528 & Valid \\
\hline 7 & $\begin{array}{l}\text { Multiple } \\
\text { pockets }\end{array}$ & 0.306 & 0.353 & Valid \\
\hline 8 & Bag capacity & 0.306 & 0.523 & Valid \\
\hline 9 & Light bag & 0.306 & 0.355 & Valid \\
\hline 10 & Material quality & 0.306 & 0.441 & Valid \\
\hline
\end{tabular}
below.

Table 2. Validation Test 


\begin{tabular}{|c|c|c|c|c|}
\hline 11 & Zipper quality & 0.306 & 0.586 & Valid \\
\hline 12 & $\begin{array}{c}\text { The quality of } \\
\text { sling }\end{array}$ & 0.306 & 0.515 & Valid \\
\hline 13 & Stitch quality & 0.306 & 0.609 & Valid \\
\hline 14 & Durable & 0.306 & 0.587 & Valid \\
\hline 15 & Warranty & 0.306 & 0.584 & Valid \\
\hline 16 & $\begin{array}{c}\text { Small bag } \\
\text { bonus }\end{array}$ & 0.306 & 0.594 & Valid \\
\hline
\end{tabular}

Source: Data is processed from research, 2020

The validity test shows that the 16 questions asked to respondents are valid.

Table 3. Reliability Test Result

\begin{tabular}{cc}
\hline \multicolumn{2}{c}{ Reliability Statistics } \\
\hline $\begin{array}{c}\text { Cronbach's } \\
\text { Alpha }\end{array}$ & N of Items \\
\hline 0.760 & 16 \\
\hline
\end{tabular}

The results of the SPSS calculation for the questionnaire reliability test show that the questionnaire is consistent. This can be seen in the alpha Crobach's value obtained which is 0.760 . It means the consistency of the questionnaire is high. (4) Data Processing stage using the QFD and SWOT methods. (5)
The Study and Analysis Stage. After the data is processed and the results are obtained, the next stage is reviewing and analyzing the research results

\section{Results and Discussion}

The following is the performance of the product attributes obtained from the results of the research questionnaire that has passed the validity and reliability tests. The results of data processing from questionnaires are taken to perform QFD Phase 1 data processing (House of Quality):

There are three aspects of the performance of product attributes: customer expectations, company products and competitor products. The performance of customer expectations is the level of customer expectations for a product. Meanwhile, the performance of the company's and competitors' products is the level of customer assessment of the company's products and competitors' products.

The performance of those product attributes is used to calculate the ratio of improvements. Repair ratio describes how big or small the company must improve product performance to match consumer expectations. After getting the repair ratio, the next step is to determine the weight of

\section{Table 4. Performance of Product Attributes}

\begin{tabular}{|c|c|c|c|c|}
\hline \multirow[b]{2}{*}{ No } & \multirow[b]{2}{*}{ Product Attribute } & \multicolumn{3}{|c|}{ Performance of Product Attributes } \\
\hline & & $\begin{array}{c}\text { Costumer } \\
\text { Expectations }\end{array}$ & $\begin{array}{c}\text { CV. Semesta } \\
\text { Agung's Product }\end{array}$ & $\begin{array}{c}\text { Competitor's } \\
\text { Product }\end{array}$ \\
\hline 1 & Affordable bag price & 4.83 & 4.57 & 4.24 \\
\hline 2 & Attractive bag color & 4.89 & 4.13 & 4.31 \\
\hline 3 & Interesting bag picture & 4.75 & 3.98 & 4.17 \\
\hline 4 & Attractive packaging design & 4.49 & 3.69 & 4.29 \\
\hline 5 & Hanging accesories & 4.04 & 2.4 & 3.49 \\
\hline 6 & Waterproof & 4.76 & 3.15 & 3.24 \\
\hline 7 & Multiple pockets & 4.52 & 3.34 & 3.52 \\
\hline 8 & Bag capacity & 4.69 & 3.89 & 3.73 \\
\hline 9 & Light bag & 3.74 & 4.17 & 4.05 \\
\hline 10 & Material quality & 4.78 & 4.34 & 4.31 \\
\hline 11 & Zipper quality & 4.58 & 4.29 & 4.14 \\
\hline 12 & The quality of sling & 4.26 & 4.23 & 3.97 \\
\hline 13 & Stitch quality & 4.74 & 4.46 & 3.89 \\
\hline 14 & Durable & 4.71 & 3.87 & 3.67 \\
\hline 15 & Warranty & 4.12 & 2.12 & 2.32 \\
\hline 16 & Small bag bonus & 3.95 & 2.38 & 3.8 \\
\hline
\end{tabular}

Source: data is processed from research, 2020 
each product attribute.

Determining the weight of $\mathrm{HOQ}$ is the final stage. By looking at the weight of $\mathrm{HOQ}$ compare to product attributes, we know the priority of product attributes that consumers want for a children's backpack.

Table 5. Weight Recapitulation

\begin{tabular}{cccc}
\hline No & Product Attribute & Score & Normalization Score \\
1 & Affordable bag price & 8.2 & $8.6 \%$ \\
2 & Attractive bag color & 7.3 & $7.6 \%$ \\
3 & Interesting bag picture & 9.4 & $9.9 \%$ \\
4 & Attractive packaging design & 5.2 & $5.5 \%$ \\
5 & Hanging accesories & 2.5 & $2.6 \%$ \\
6 & Waterproof & 7.6 & $8.0 \%$ \\
7 & Multiple pockets & 5.7 & $6.1 \%$ \\
8 & Bag capacity & 6.2 & $6.5 \%$ \\
9 & Light bag & 0.7 & $0.8 \%$ \\
10 & Material quality & 8.6 & $9.1 \%$ \\
11 & Zipper quality & 5.6 & $5.9 \%$ \\
12 & The quality of sling & 5.7 & $6.0 \%$ \\
13 & Stitch quality & 8.4 & $8.9 \%$ \\
14 & Durable & 7.8 & $8.2 \%$ \\
15 & Warranty & 4.5 & $4.8 \%$ \\
16 & Small bag bonus & 1.5 & $1.6 \%$ \\
\hline
\end{tabular}

Source: Data is processed from research, 2020

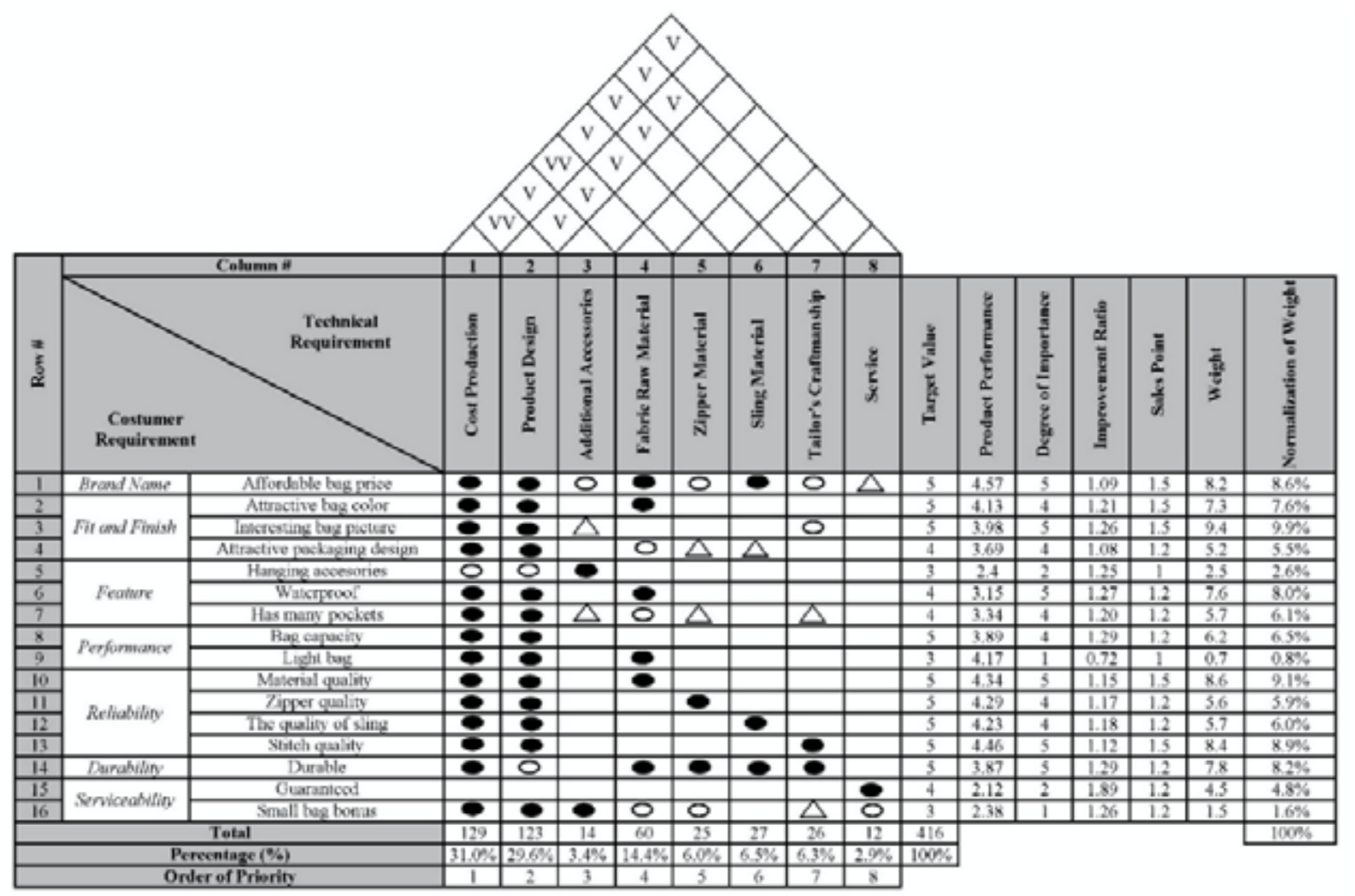

Figure 2. House Of Quality Matrix 
Figure 2 explains the determination of the relationship between consumer needs and technical characteristics and shows the level of strength of the relationship between product attributes (consumer needs) and technical characteristics. An assessment of the level of strength between the two can be done using numbers or symbols, namely 9 (for very strong relationship or), 3 (strong relationship orO), and 1 (weak relationship or $\triangle$ ). Based on the weight of consumer needs, there are attributes that gain the highest weight and become priorities that must be considered by the company, which are attractive bag motifs/images, quality of materials, quality of stitches, affordable, and durable bag prices. Meanwhile, based on the technical characteristics, the order of the percentage $(\%)$ from the highest to the lowest is production cost of $31.0 \%$, product design of $29.6 \%$, fabric raw materials of $14.4 \%$, raw materials of sling by $6.5 \%$, tailor expertise by $6.3 \%$, zipper raw materials by $6.0 \%$, additional accessories by $3.4 \%$, and services by $2.9 \%$.

\section{Determination of Internal Factors}

The company's internal factors are obtained from the comparison of the company's product performance and competitors as well as considering the weight of product attributes in the House of Quality matrix.

After determining the internal factors, the calculation of the internal factor evaluation (EFE) can be seen in table 7.

Table 6. Attribute Work Comparison

\begin{tabular}{ccccc}
\hline No & Product Attribute & Score & $\begin{array}{r}\text { CV. Semesta Agung's } \\
\text { Product Performance }\end{array}$ & $\begin{array}{c}\text { Competitor's } \\
\text { Product } \\
\text { Performance }\end{array}$ \\
\hline 1 & Affordable bag price & $8.6 \%$ & 4.57 & 4.24 \\
2 & Attractive bag color & $7.6 \%$ & 4.13 & 4.31 \\
3 & Interesting bag picture & $9.9 \%$ & 3.98 & 4.17 \\
4 & Attractive packaging design & $5.5 \%$ & 3.69 & 4.29 \\
5 & Hanging accesories & $2.6 \%$ & 2.4 & 3.49 \\
6 & Waterproof & $8.0 \%$ & 3.15 & 3.24 \\
7 & Multiple pockets & $6.1 \%$ & 3.34 & 3.52 \\
8 & Bag capacity & $6.5 \%$ & 3.89 & 3.73 \\
9 & Light bag & $0.8 \%$ & 4.17 & 4.05 \\
10 & Material quality & $9.1 \%$ & 4.34 & 4.31 \\
11 & Zipper quality & $5.9 \%$ & 4.29 & 3.14 \\
12 & The quality of sling & $6.0 \%$ & 4.23 & 3.97 \\
13 & Stitch quality & $8.9 \%$ & 4.46 & 3.89 \\
14 & Durable & $8.2 \%$ & 3.87 & 2.37 \\
15 & Warranty & $4.8 \%$ & 2.12 & 3.8 \\
\hline 16 & Small bag bonus & $1.6 \%$ & 2.38 & \\
\hline
\end{tabular}

Source: Data is processed from research, 2020

Table 7. Internal Factors

\begin{tabular}{lcccc}
\hline No & $\begin{array}{c}\text { Key Internal Factors } \\
\text { Strength }\end{array}$ & Score & Rating & Total \\
\hline 1 & The price of CV SA product is known to be affordable & 0.071 & 3 & 0.213 \\
2 & Bag Products of CV SA have a large enough capacity & 0.058 & 3 & 0.174 \\
3 & Bag products of CV SA have good quality fabrics & 0.06 & 3 & 0.18 \\
4 & Bag product of CV SA have good quality zippers & 0.051 & 2 & 0.102 \\
5 & Bag product of CV SA have good quality sling & 0.065 & 3 & 0.195 \\
6 & Bag product of CV SA have good quality stitch & 0.069 & 3 & 0.207 \\
7 & Bag product of CV SA is known as a durable product & 0.071 & 3 & 0.213
\end{tabular}




\begin{tabular}{ccccc}
8 & Bag product of CV SA is quite light & 0.053 & 3 & 0.159 \\
\hline & Total Score of Strength & $\mathbf{0 . 4 9 8}$ & $\mathbf{2 3}$ & $\mathbf{1 . 4 4 3}$ \\
\hline & Weakness & & & \\
10 & The color of CV SA bag is less attractive & 0.067 & 3 & 0.201 \\
11 & The image/motif of CV SA bag is less attractive & 0.066 & 3 & 0.198 \\
12 & Bag packaging design is less attractive & 0.065 & 3 & 0.195 \\
13 & Bag products of CV SA do not have additional accessories & 0.043 & 2 & 0.086 \\
14 & Bag products of CV SA are not waterproof & 0.069 & 3 & 0.207 \\
15 & Bag products of CV SA do not have many/multiple pockets & 0.067 & 3 & 0.201 \\
16 & Bag products of CV SA do not have a warranty & 0.057 & 3 & 0.171 \\
\hline & No small bag bonus (as a gift) & 0.069 & 3 & 0.207 \\
\hline & Total Score of Weakness & $\mathbf{0 . 5 0 3}$ & $\mathbf{2 3}$ & $\mathbf{1 . 4 6 6}$ \\
\hline
\end{tabular}

Source: data is processed from research, 2020

Internal Factor Evaluation (IFE) Matrix is an internal factor that will influence the development of the company's business which consists of existing strengths and weaknesses. The total weight calculation from the internal matrix is 1.00 with a rating value of 46 and the total weight multiplied by the rating is 2,905 .

\section{Determination of External Factors}

Determination of external factors is conducted to find out the threats and opportunities for the company. External factors are obtained by conducting brainstorming (interviews) with the company. External factors can be seen in table 8 .

Table 8. Matrix of EFE

\begin{tabular}{|c|c|c|c|c|}
\hline No & $\begin{array}{l}\text { Key External Factors } \\
\text { Opportunities }\end{array}$ & Score & Rating & Total \\
\hline 1 & The number of children in Bandung city continues to increase & 0.0808 & 3 & 0.242 \\
\hline 2 & Bandung city has a large market for children's products & 0.0888 & 4 & 0.355 \\
\hline 3 & $\begin{array}{l}\text { Many tourists come to Bandung city since it is a shopping tourist } \\
\text { destination }\end{array}$ & 0.0784 & 3 & 0.235 \\
\hline 4 & Having a good business relationship with suppliers & 0.0528 & 2 & 0.106 \\
\hline 5 & Bag product of CV SA have good quality sling & 0.0648 & 3 & 0.194 \\
\hline 6 & Competitors become a benchmark for improving product quality & 0.0864 & 4 & 0.346 \\
\hline 7 & Development of technology that eases the transaction & 0.08 & 3 & 0.24 \\
\hline \multirow{2}{*}{\multicolumn{5}{|c|}{$\begin{array}{l}\text { Total Score of Opportunities } \\
\text { Threats }\end{array}$}} \\
\hline & & & & \\
\hline 8 & The price of material which continues to increase & 0.0808 & 3 & 0.2424 \\
\hline 9 & Competition with other competitor that sell similar products & 0.0872 & 4 & 0.3488 \\
\hline 10 & Competitor sell the similar products with lower price & 0.088 & 4 & 0.352 \\
\hline 11 & Complaints about the products through word of mouth & 0.0816 & 3 & 0.2448 \\
\hline 12 & Bargaining power of consumers is quite high & 0.0784 & 3 & 0.2352 \\
\hline 13 & $\begin{array}{l}\text { Development of technology leads to rampant counterfeiting and product } \\
\text { fraud }\end{array}$ & 0.052 & 2 & 0.104 \\
\hline & Total Score of Threats & 0.468 & 19 & 1.527 \\
\hline & Total Internal & 1 & 41 & 3.246 \\
\hline
\end{tabular}

Source: data is processed from research, 2020 
The EFE matrix is an external factor that will affect the development of the company's business which consists of opportunities and threats. The total weight calculation from the internal matrix is 1.00 with a rating value of 39 and the total weight multiplied by the rating is 3.128 .

\section{Internal and External Matrix}

IE matrix is a matrix that displays the company's position based on the weight calculation of internal and external analysis. The evaluation results from the EFE and IFE matrices are used as input to the IE matrix. The horizontal axis of this IE matrix is the total IFE weight value of 2.905, while the vertical axis is the total EFE weight value of 3.128. IE matrix can be seen in figure 3 .

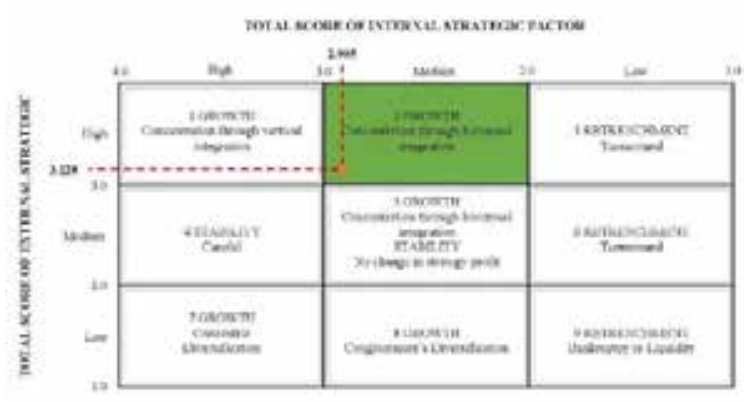

Figure 3. Matriks IE
Based on the IE matrix above, the company position is at number 2 , which is Growth Strategy. The cell positions of 1, 2 and 4 can be called growth and building. Intensive strategies that can be done are market penetration, market development or product development.

Growth Strategy through horizontal integration is an effort to expand the company by constructing building in other locations or expanding another method of marketing and increase the types of products. Therefore, the company should build several shops in different locations, so that products are not only distributed in one place. In addition, the company should develop other types of bag products.

\section{SWOT Matrix}

The SWOT matrix is a very important step in determining a strategy for the company. The SWOT matrix formulation is carried out after obtaining the company's internal and external factors and knowing their weights. From this matrix, it will be known what marketing strategies the company must undertake. The SWOT matrix can be seen in Table 9.

Table 9. Matrix SWOT

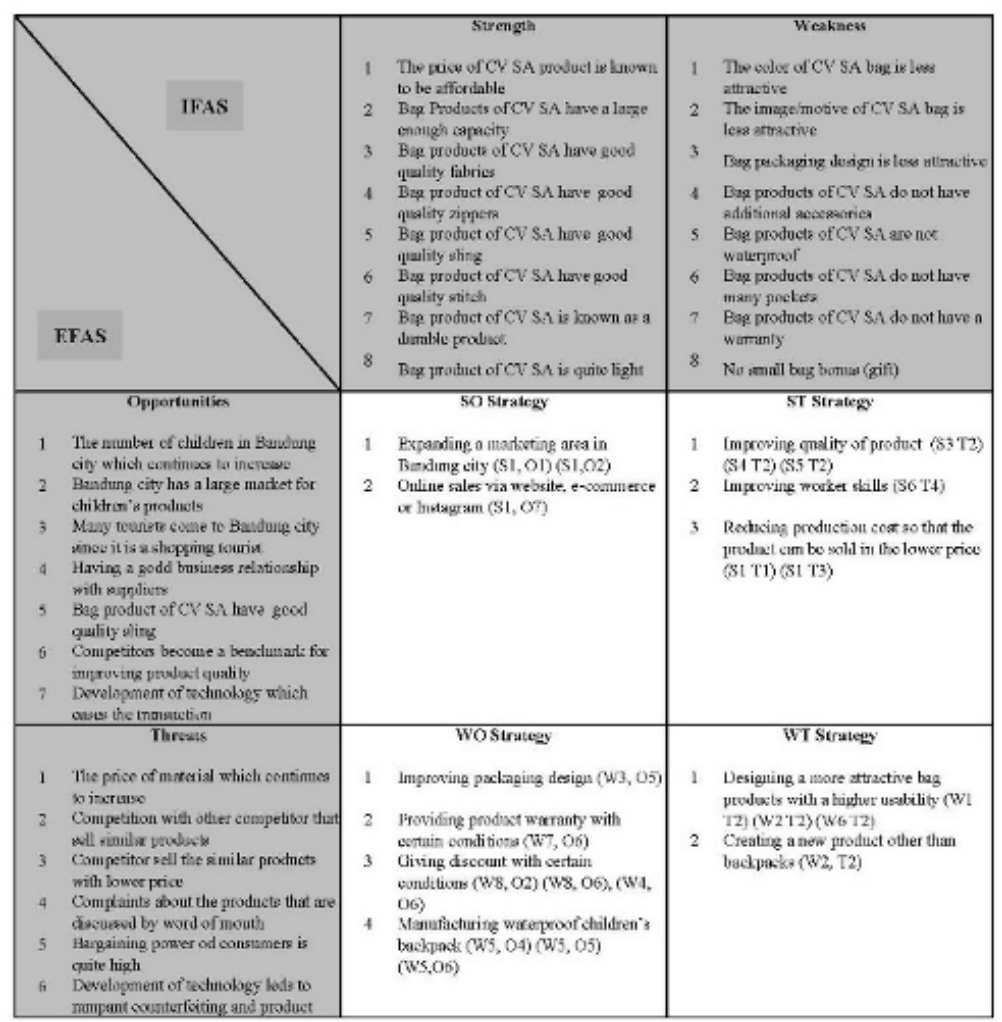

Source: Data is processed from research, 2020 


\section{Conclusion}

Based on the results of research and discussion, the following conclusions can be drawn. There are several priority product attributes that consumers pay attention to in children's backpacks, namely attractive bag motifs/images, quality of materials, quality of stitches, affordable prices, and durable products. Marketing strategies that can be carried out by companies that are formulated using the SWOT matrix are as follows: SO strategy by expanding the marketing area in Bandung city and selling products online; WO strategy by improving the design of product packaging, providing product warranty, giving a discount, and creating waterproof children's backpack; ST strategy by improving product quality and workers' skills, and reducing production costs in order to sell cheaper products; WT's strategy by designing a more attractive children's backpack product design and creating new types of products other than backpacks.

\section{Acknowledgment}

The Researchers would like to thank Lembaga Penelitian dan Pengabdian kepada Masyarakat (LPPM) Universitas Islam Bandung for funding this research through Penelitian Dosen Utama (PDU) scheme in the 2019 - 2020 academic year.

\section{References}

Andronikidis, A., A. C. Georgiou, K. Gotzamani, and K. Kamvysi. 2009. "The Application of Quality Function Deployment in Service Quality Management." The TQM Journal 21 (4): 319-333.

Blocher, E. J., Stout, D. E., \& Cokins, G. (2011). Manajemen Biaya Penekanan Strategis. Jakarta: Salemba Empat.

Besterfield, D.H. et.al. 2012. Total Quality Management Revised Third Edision. South Asia : Pearson Education Push Print services.

Badan Pusat Stastistik (BPS). (2017). Jumlah Unit Industri Kecil Menengah di Kota Bandung. Badan Pusat Statistik kota Bandung.

David. 2009. Manajemen Strategis Konsep Edisi 12. Jakarta: Salemba Empat.

David, F. R. (2016). Strategic management: A competitive advantaga2ze approach, concepts and cases. Harlow : Pearson.

Dehe, B., \& Bamford, D. (2017). Quality
Function Deployment and operational design decisions - a healthcare infrastructure development case study. Production Planning \& Control, 28(14), 11771192. d oi:09537287.2017.1350767/10.1080.

E.P. Nurlaili, (2012)., "Penerapan QFD dan Analisis SWOT Untuk Menetapkan Strategi

Peningkatan Kualitas Produk Sayuran Segar"., Jurnal Teknik Industri, Vol. 1, No. 3., halaman 12-21.

Gaspersz, Vincent. "Total Quality Management", Edisi 1 Halaman 33. PT. Gramedia Pustaka Utama, Jakarta 2003

Javandira, C., \& Gama, A. W. S. (2018). Analisis Faktor Lingkungan Eksternal Dan Internal Usaha Sayur Organik (Studi Kasus Pada UD. Eka Setia Lestari Di Baturiti). JUIMA: JURNAL ILMU MANAJEMEN, 8(2), 37-50.

Koo, L.C. and Koo, H. (2007) 'Holistic approach for diagnosing, prioritising, implementing and monitoring effective strategies through synergetic fusion of SWOT, Balanced Scorecard and QFD', World Review of Entrepreneurship, Management and Sustainable Development, Vol. 3, No. 1, pp.62-78.

Murali, S., S. Pugazhendhi, and C. Muralidharan. 2016. "Integration of IPA and QFD to Assess the Service Quality and to Identify after Sales Service Strategies to Improve Customer Satisfaction-A Case Study." Production Planning and Control 27 (5): 394-407.

Munadi., Ernawati \& Salim., Zamroni (2015), Info komoditi Pakaian Jadi, Badan Pengkajian dan Pengembangan Kebijakan Perdagangan Al Mawardi Prima, Jakarta.

Prabowo, R., \& Zoelangga, M. I. (2019). Pengembangan Produk Power Charger Portable dengan Menggunakan Metode Quality Function Deployment (QFD). Jurnal Rekayasa Sistem Industri, 8(1), $55-62$.

Rucitra, Andan Linggar., (2020) The Implementation of Integrated Quality Function Deployment (QFD) and SWOT Analysis in the Quality Improvement Strategy of Jackfruit Chips. Jurnal Teknologi dan Manajemen Agroindustri Volume 9 Issue $1 .$, p. 35-42.

Rangkuti, Freddy. 2013. Analisis SWOT : Teknik Membedah Kasus Bisnis. Jakarta : PT. Gramedia Pustaka Utama.

Subhan, Ali., (2017). Perumusan Strategi Fakultas Teknik Universitas Suryakancana menggunakan Model Gabungan Balanced 
Scorecard, Sun-Tzu, Quality Function Deployment \& Analisis SWOT, Jurnal Media Teknik \& Sistem Industri, Vol. 1 hal.50-59.

Ulrich, K. T., \& Eppinger, S. D. (2001). Perancangan Dan Pengembangan Produk. Jakarta: Salemba Teknika.

Wanti, S., Taufiqurrahman, \& Rahayu, D. D. (2014). Analisis strategi keunggulan bersaing dengan pendekatan analisis
SWOT pada Spartan Gym Pekanbaru. Jurnal Online Mahasiswa Fakultas Ekonomi Universitas Riau, 1(2), 1-15.

Wijaya, H., \& Sirine, H. (2016). Strategi segmenting, targeting, positioning serta strategi harga pada perusahaan Kecap Blekok di Cilacap. AJIE (Asian Journal of Innovation and Entrepreneurship), 1(3), 175-190. 